\title{
Towards a green modernization development discourse: the new green revolution in Africa
}

\author{
Mikael Bergius ${ }^{1}$ \\ Jill Tove Buseth \\ Norwegian University of Life Sciences (NMBU), Norway
}

\begin{abstract}
Since the Rio+20 conference, 'greening' economies and growth has been key in international politics. Leading policy actors and businesses frame the emerging green economy as an opportunity to realize a triple-bottom line - people, planet and profit - and support sustainable development. In practice, two key trends stand out: in the global North, the main component of the green shift seems to imply technological and market-based solutions in the renewable energy sector. While this is also important in the global South, here green economy implementation is often interpreted as environmental protection along with modernization of, and shifts in access to and control over, natural resources ('green sectors'). In the case of the latter, combined with persisting high rates of poverty, we claim that the post-Rio +20 context has revitalized a 'green' version of modernization to become the leading discourse and approach within international development; namely green modernization. A wide range of development initiatives across the global South - with significant support from international businesses amidst a general private turn of aid - are framed in this light. We use the new, green revolution in Africa to illustrate how modernization discourses are reasserted under the green economy. What is new at the current conjuncture is the way in which powerful actors adopt and promote green narratives around long-standing modernization ideas. They recast the modernization trope as 'green.' In particular, we focus our discussion on three linked components; technology and 'productivism', the role of capital and 'underutilized' resources, and, lastly, mobility of land and people.
\end{abstract}

Keywords: green economy; green modernization; the new green revolution in Africa; agri-business; climate smart agriculture; development discourse

\section{Résumé}

Depuis la conférence Rio + 20, les économies «vertes» et la croissance économique ont été essentielles dans la politique internationale. Les principaux acteurs politiques et les entreprises considèrent l'économie verte émergente comme une opportunité de réaliser un triple résultat - pour les personnes, la planète et les profits et de soutenir le développement durable. En pratique, deux tendances clés se dégagent: dans le Nord, la principale composante du virage vert semble impliquer des solutions technologiques et fondées sur le marché dans le secteur des énergies renouvelables. Bien que cela soit également important dans les pays du Sud, la mise en œuvre de l'économie verte est souvent interprétée comme une protection de l'environnement accompagnée d'une modernisation et de modifications de l'accès aux ressources naturelles et de leur contrôle

\footnotetext{
${ }^{1}$ We are both PhD fellows at Department of International Environment and Development Studies (Noragric), Norwegian University of Life Sciences (NMBU). Email: mikael.bergius[at]nmbu.no and jill.buseth[at]nmbu.no. We would like to thank Tor A. Benjaminsen, Ola Westengen, Paul Belesky, Frances Cleaver and members of the development studies research group UMU at Oslo Metropolitan University for comments on earlier versions of this article. Thanks also to the editors of the Journal of Political Ecology and the anonymous reviewer for thoughtful and helpful comments. We acknowledge support from the Norwegian Research Council through the 'Greenmentality' project [project number 250975]. We have contributed equally to the research and writing of this article.
} 
(«secteurs verts»). Dans le cas de ce dernier, associé à des taux de pauvreté toujours élevés, nous affirmons que le contexte post-Rio +20 a revitalisé une version «verte» de la modernisation pour devenir le discours et l'approche phare du développement international; à savoir la modernisation verte. Un large éventail d'initiatives de développement dans les pays du Sud - avec l'appui important d'entreprises internationales dans le contexte d'une aide privée générale - s'inscrit dans cette perspective. Nous utilisons la nouvelle révolution verte en Afrique pour illustrer la manière dont les discours sur la modernisation sont réaffirmés dans le cadre de l'économie verte. Ce qui est nouveau dans la conjoncture actuelle est la manière dont des acteurs puissants adoptent et promeuvent des récits écologiques autour d'idées de modernisation de longue date. Ils ont qualifié le trope de modernisation de «vert». En particulier, nous concentrons notre discussion sur trois composantes liées; la technologie et le «productivisme», le rôle du capital et des ressources «sousutilisées» et, enfin, la mobilité des terres et des personnes.

Mots-clés: économie verte; modernisation verte; la nouvelle révolution verte en Afrique; secteur agroalimentaire; agriculture intelligente face au climat; discours de développement

\section{Resumen}

A partir de la reunión de Rio+20, las economías y el crecimiento "verdes" han sido claves en la política internacional. Importantes actores de políticas y negocios, plantean la naciente economía verde como una oportunidad para conseguir un triple resultado - gente, planeta y ganancia - y respaldar el desarrollo sostenible. En la práctica, destacan dos corrientes principales: en el Hemisferio Norte, el principal componente del giro verde parece implicar para el sector de la energías renovables, soluciones tecnológicas y basadas en el mercado. Mientras que esto también es importante en el Hemisferio Sur, ahí la implementación de la economía verde es a menudo interpretada como protección del medio ambiente a la par de la modernización de, y los cambios en el acceso y control de recursos naturales ("sectores verdes"). Afirmamos que este último, combinado con los altos índices de pobreza que persisten, ha revitalizado una versión "verde" de la modernización, para convertirse en el principal discurso y aproximación dentro del desarrollo internacional, a saber la modernización verde, en el contexto posterior a Rio+20. Una amplia variedad de iniciativas de desarrollo en el Hemisferio Sur - con importante apoyo de negocios internacionales en un generalizado giro privado de los apoyos - se encuentran en el marco de este contexto. Nos basamos en la nueva Revolución Verde en África para ilustrar cómo los discursos de modernización se han reafirmado bajo la economía verde. Lo novedoso en esta coyuntura es la manera en que los actores poderosos adoptan e impulsan narrativas verdes sobre antiguas ideas de modernización, y hacen un rediseño del tropo de modernización como "verde". Particularmente enfocamos nuestra discusión en tres componentes vinculados: tecnología y "productivismo", el papel del capital y los recursos "subutilizados", y finalmente, la movilidad de la tierra y la gente.

Palabras clave: economía verde, modernización verde, la nueva Revolución Verde en África, agroindustria, agricultura climáticamente inteligente, discurso sobre el desarrollo

\section{Introduction}

"We need a Green Revolution in a Green Economy, but one with a capital G" said Achim Steiner, former Executive Director of the United Nations Environment Program (Deen 2009). His remarks - presented at the Global Ministerial Environment Forum in Nairobi in 2009 during the launch of the report The environmental food crisis - represents an emerging trend combining the green economy, which became the main focus of the Rio+20 conference in 2012, with calls for a new, green revolution in Africa. This conceptual fusion - which resonated across the development industry as well as the private sector - proposes a 'greener' repetition of the original Green Revolution (the Consultative Group of International Agriculture Research (CGIAR) 1996; Conway 1997) to feed a growing world population projected to reach 9 billion by 2050 sustainably (Gates 2009; Horlings and Marsden 2011; Patel 2012).

Steiner's remarks reflect a more general environmental concern in recent decades. Particularly since the Rio+20 conference, 'greening' economies and growth has been at the center of international politics and economies. Leading policy actors and businesses often frame the emerging green economy as an opportunity 
to realize a triple-bottom line - people, planet and profit - in support of the long term vision of sustainable development (World Commission on Environment and Development (WCED) 1987). In other words, while a range of different interpretations of the green economy exist, the dominant understanding tends to emphasize the need for investments to turn capitalism and development in a green direction.

In practice, the green economy unfolds in different ways with a broad range of initiatives being carried out under 'green' umbrellas. However, two key trends stand out: In the global North, the main components in the green economy transition seem to imply technological and market-based solutions to existing industrial sectors as well as fiscal instruments in environmental governance. While this is also important in the global South, green economy implementation in these parts of the world - often initiated from the North - frequently supposes environmental protection along with modernization of, and/ or shifts in access to and control over forestry, freshwater, fisheries, energy and agriculture, sometimes overlapping 'green sectors' (Bailey and Caprotti 2014; Brown et al. 2014; United Nations Environment Program (UNEP) 2011a).

These trends, combined with persisting high rates of poverty, we claim, have revitalized modernization to become a leading discourse and approach within contemporary international development. Traditional modernization thinking spelled out a geographical divide between the 'progressive' cores of 'modernity' and the 'lagging' peripheries of 'tradition.' The development and modernization process insinuated a stage-wise upgrading of society through progressive control over nature and resources via rigorous application of capital and technology. In the post-Rio+20 context, these ideas seem to reappear in the form of green modernization. A wide range of development initiatives and projects across the global South are now framed in this light. This is particularly evident in, but not limited to, the agriculture sector in Africa, where proponents of largescale investments for food, ('green') fuels or carbon sinking assert that green narratives exist in enduring modernization discourses.

This occurs amidst a turn towards the private sector and business in international development - often through public-private partnerships - since the converging food, finance and fuel crises of the mid 2000s. Green sectors in the global South have become important outlets for international capital in recent years reinforcing a contemporary cycle of 'material expansion' in this stage of capitalism (Bergius, Benjaminsen and Widgren 2018; Engström and Hajdu 2018; Kröger 2013; Kröger 2015; Patel and Moore 2017). From this perspective, the green economy emerges as a new 'frontier' (Patel and Moore 2017), or a 'spatial fix' in capitalist reorganization (Harvey 1981, 2001, 2014), in which capital and markets are expected to deliver growth and technological advancements to those in need (Brockington 2012).

Scholars have written extensively about the turn towards forms of 'green capitalism' (Tienhaara 2014; Wanner 2015). Our contribution lies mainly in demonstrating how modernization has also taken a green turn and resurfaced in the development discourse in the wake of the green economy. To illustrate this, we use the case of the new green revolution in Africa. We argue that what is new is the way in which powerful actors adopt and promote green narratives around what is essentially long-standing modernization ideas to recast the modernization trope as 'green'; namely, green modernization.

The new green revolution for Africa is an eloquent example of green modernization. Undergirded by neo-Malthusian ideas, its stated objective is development through poverty reduction and food security, it is permeated by green rhetoric, and it is private sector led and capital/ techno-centred, with a wide array of public-private investment platforms. The new green revolution transpires within the broader green economy framework, and the two, green revolution and green economy, frequently merge under new terms such as Agriculture Green Growth (Southern Agricultural Growth Corridor of Tanzania (SAGCOT) 2013) or Climate Smart Agriculture (the Food and Agriculture Organization of the United Nations (FAO) 2010). As Bill Gates, a key proponent of the new green revolution through the Bill and Melinda Gates Foundation, asserts, "... we need both productivity and sustainability - and there is no reason we can't have both $[\ldots]$ the next Green revolution has to be greener than the first" (Gates 2009).

In other words, 'progress' under the new green revolution - reflecting the dominant green economy discourse (Bergius et al. 2018; Buseth 2017) - signifies a trajectory of agrarian change that focuses on productivity growth and environmental protection via capital-intensive farming methods and new settlement patterns. Meanwhile, critics question the inclusivity of these green modernization strategies in agriculture, and 
express worry about what they see as substantial blind spots when it comes to issues of power and distribution (Clapp, Newell and Brent 2018; Holt-Giménez and Altieri 2012; McKeon 2015; Moseley 2017; Patel 2012). Indeed, these are core concerns of political ecologists (Moseley 2017; Peet, Robbins and Watts 2011; Robbins 2012; Tilzey 2018). As Moseley (2017) argues, a political ecology approach is useful to unmask the power structures and key assumptions underpinning the new green revolution. In this article we seek to do this by situating and historizing the new green revolution for Africa within a wider green modernization development discourse.

This article is primarily based on a review of relevant academic and policy literature. In addition, research undertaken since 2015 at local and national level in Tanzania, as well as at the international level through key stakeholder interviews and conference ethnography, provide an overall contextual background to our discussion. ${ }^{2}$

Following this introduction, the article proceeds with an outline of modernization thinking to illustrate its origins, persistence and contemporary 'green' turn in development discourses. After a brief discussion of this green turn in development policy, we demonstrate in the last part of the article how an emerging green modernization discourse manifests in the new green revolution for Africa. In particular, we focus our discussion on three interlinked components that we see as key to the discourse; technology and 'productivism', the role of capital and 'underutilized' resources, and mobility of land and people. Finally, we provide some concluding reflections.

\section{From modernization to green modernization}

Over time, the concepts of modernization and development have carried variegated meanings. Contemporary usage dates from the commencement of the post-war 'development project' (McMichael 2012). However, its historical roots go back to a patchwork of ideas rooted in $16^{\text {th }}$ and $17^{\text {th }}$ century European enlightenment philosophy.

During this time, what Patel and Moore (2017: 46) describes as an "intellectual revolution" took place, which set the stage for dualistic ways of understanding the world: seeing nature as an entity distinct from society. The Cartesian ontology that underwrites this divide distinguished between res cogitans (thinking things) and res extensa (extended things). The former refers to humans, while the latter describes all extended things; those that are not human and therefore not thinking things. In Descartes' view, res cogitans had to become the "lords and masters" (Descartes 1985: 142-143) of res extensa. This ontological construction underpins much of the enlightenment philosophy: "science should as it were torture nature's secrets out of her" (Bacon n.d. in Amrine 2010). This dichotomy has been considered foundational in shaping capitalist development - including the Green Revolution (Eddens 2017) - through its organization of the world in a way that mirrors the power and interests of some humans (the 'civilized' belonging to society) at the expense of others (the 'savages' belonging to nature) (Patel and Moore 2017; Peet and Hartwick 2015). ${ }^{3}$

Cartesian dualism influenced early thinking around modernization and development. Ideas of progress combined environmental determinism with the rationalist aptitude of some humans to master 'nature's secrets' through science and technology (Parsons 1973; Peet and Hartwick 2015; Spencer 1898). Parsons (1973) later referred to this as society's 'adaptive upgrading'; a process by which the application of the rationalist mind to nature prompts a gradual differentiation of special industries from agriculture (Goldthorpe 1975). These ideas have ultimately spelled out an assumed geographic binary between 'modern' cores and peripheries of

\footnotetext{
2 Because of this several examples used in this article are from Tanzania. However, the trends and processes we discuss are highly relevant across Sub-Saharan Africa (see for example Daño 2007; Dawson, Martin and Sikor, 2016; De Schutter 2015; Eddens 2017; McKeon 2014; Moseley 2017; Moseley, Schnurr and Kerr (ed.) 2017; Patel et al. 2015; Westengen et al. 2017).

${ }^{3}$ As Patel and Moore (2017: 52) write, "This means Descartes philosophical abstractions were practical instruments of domination" with material force. Similarly, Peet and Hartwick (2015: 31) emphasize, "the Enlightenment philosophers were thinking on behalf of early capitalist white men, and their rights and liberties, not the rights of the workers, nor the peasants, and definitely not women, nor black or brown people."
} 
'tradional backwardness'. By progressively controlling nature, the cores of modernity exemplified the 'progress' towards which peripheries locked in the pre-scientific chains of tradition should aim, and was also endowed with competitive advantages over them.

The rule of (some) humans over nature and the resulting 'separation' from it was evidence of progress and a manifestation of modernity. Embedded in a wider cycle of frontier expansion over capitalism's longuedurée, the 'core of modernity' saw as its moral imperative to proliferate the fruits of its scientific progress and liberate the inferior humans from their backwardness - first via colonialism. As French colonial politician and historian, Albert Sarraut, wrote in 1923:

It should not be forgotten that we are centuries ahead of them, long centuries during which slowly and painfully, through a lengthy effort of research, invention, meditation and intellectual progress aided by the very influence of our temperate climate - a magnificent heritage of sciences, experience and moral superiority has taken shape, which makes us eminently entitled to protect and lead the races lagging behind us. (in Rist 2008: 58) ${ }^{4}$

Then secondly through 'development'.

\section{Modernization theory for development}

"... we must embark on a bold new program", President Truman (1949) said towards the end of his inauguration speech,

...for making the benefits of our scientific advances and industrial progress available for the improvement and growth of underdeveloped areas [...]. Greater production is the key to prosperity and peace. And the key to greater production is a wider and more vigorous application of modern scientific and technical knowledge.

Truman's speech signaled the launch of the development project (McMichael 2012) and eloquently reflects the global level schism between primitive and prosperous industrial-capitalist areas. The distinction in enlightenment philosophy between nature and society finds its contemporary discursive representations in the backward/advanced, traditional/modern and underdeveloped/developed binaries that permeate 'development.'

Modernization theory sought to describe the key mechanisms that drive the emergence of modern institutions in countries. Development in this context, as today, was defined according to schisms, which, in the words of Bernstein (1971: 147), depicts "modernization as a process in which modern elements accumulate and traditional elements are displaced." Development was assumed to be synonymous with most of what was considered Western - mental models (rationalism), culture and economic and political institutions - and thus modern (Peet and Hartwick 2015). Economist and US government advisor Walt W. Rostow's influential book, Stages of economic growth - a non-communist manifesto, provided the blueprint (1960; Figure 1). Rostow's evolutionary theory of development accentuated economic growth both as a means and as an end, with the ultimate telos being signified by societies of 'high mass consumption.' The West, and US in particular, epitomized the consumerist economy towards which all other societies should aspire.

${ }^{4}$ This quote is an English translation from Sarraut's La Mise en valeur des colonies françaises (1923: 118-119). The original text, in French, reads:

Nous avons tout de même sur elles, il ne faut pas l'oublier, des siècles d'avance, de longs siècles au cours desquels, lentement et douloureusement, par l'effort prolongé de la recherche, de l'invention, de la méditation, d'un progrès intellectuel avantagé par l'influence même de notre climat tempéré, s'est constitué le patrimoine magnifique de science, d'expérience, de supériorité morale qui nous confère le titre éniinent à la protection et à la direction des races en retard sur nous. 


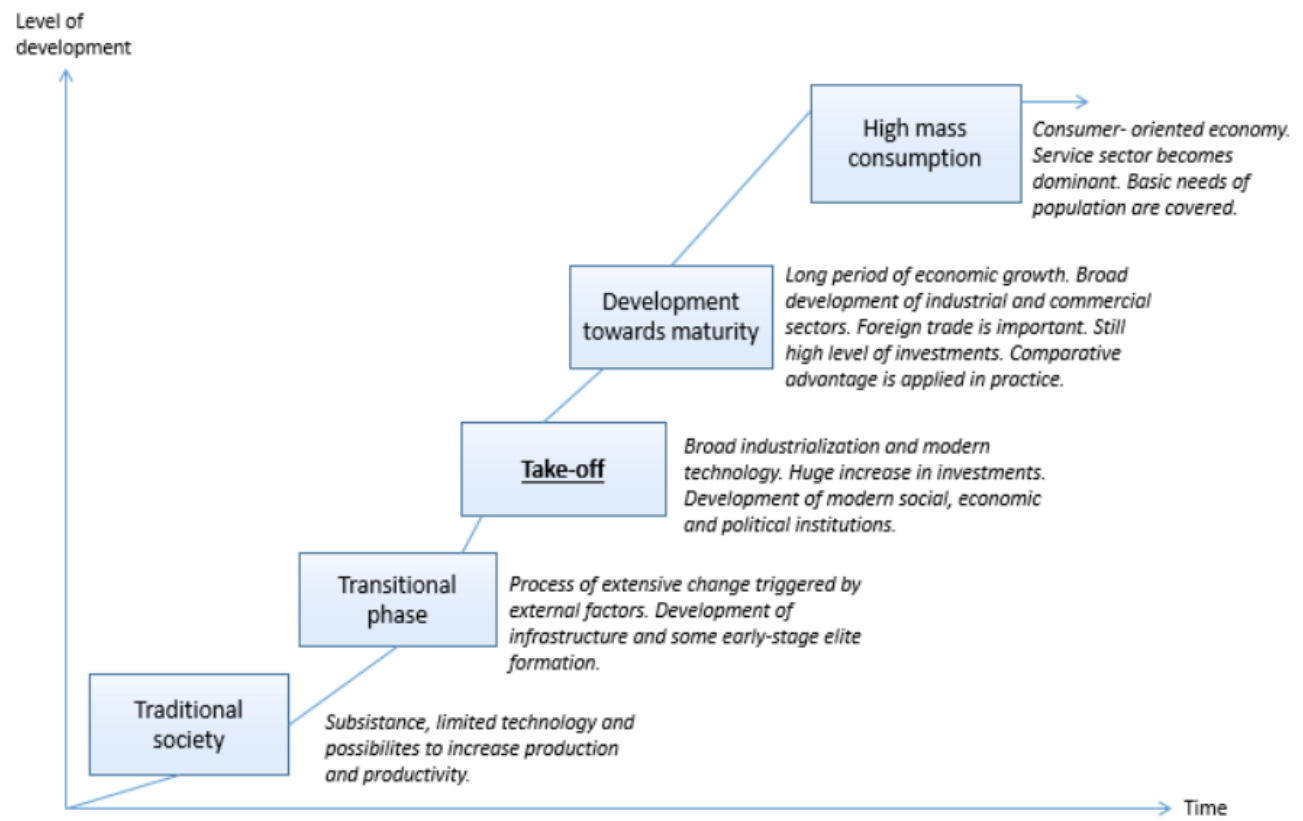

Figure 1: Rostow's 'stages of economic growth' based on Rostow (1960).

Lewis (1954) claimed that the global traditional-modern duality was also a feature salient to economies within the global South. There was the modern (capitalist) sector coexisting alongside a traditional (subsistence) sector yet to be 'captured' by the progressive values of capitalism (Hydén 1980; Lewis 1954). According to Hydén (1980), the traditional sector was governed by a non-entrepeneurial mentality - an "economy of affection" - that impedes the expanded reproduction of capital necessary for industrial development. ${ }^{5}$ The key feature of the dual economy, as advanced by Lewis (1954), was the ostensibly low productivity of the traditional sector relative to the modern, denoting overall productivity losses in the economy. This suggested that living standards and the overall performance of the economy would be improved - if 'fructified' by capital to fill development 'financing gaps' (Easterly 1999; Lewis 1954: 147) - via a gradual labor migration towards the modern sector. The mission of development became to capture and modernize uncaptured economies (Hydén 1980).

To Lewis (1954), the uncaptured subsistence sector represented a cheap pool of "unlimited supplies of labor" and embodied an opportunity for capitalists in 'advanced' areas to alleviate falling rates of accumulation through capital exports. ${ }^{6}$ Capital inflow would in turn contribute to increased saving rates and generate cycles of re-investable capital and raising productivity and incomes (Galenson and Leibenstein 1955; Lewis 1954). Indeed, the idea of migrating out of the traditional sector finds its equivalent in contemporary calls for investments in the global South and represents - with other "cheap things" (Patel and Moore 2017) a key component in capitalism's continuously expanding frontiers.

\footnotetext{
5 This is also a theme in one of Parsons' (2005 [1951]) five dichotomic 'pattern variables' where he argues that affective neutrality (a feature of modern society), as opposed to affectivity, "is shown when an actor postpones or renounces immediate gratifications, and so is related to capital formation in industrializing socieities which involves decisions to save and invest rather than expend resources in current consumption" (Goldthorpe 1975: 9)

${ }^{6}$ A process similar to what Harvey $(1981,2014)$ conceptualize as capital's 'spatial-fix' (see below).
} 
In general, modernization theories explain the "accumulation of modern elements" in society (Bernstein 1971) as a relationship and process of diffusion across the binary divide (Mouzelis 1980). ${ }^{7}$ Lewis argued that 'underdeveloped' countries were characterized by

...not one island of expanding capitalist employment, surrounded by a vast sea of subsistence workers, but rather a number of such tiny islands...We find a few industries highly capitalized [...] side by side with the most primitive techniques [and] a few highly capitalized plantations, surrounded by a sea of peasants. But we find the same contrasts also outside their economic life. There are one or two modern towns [...] and villages which might almost belong to another planet. There is the same contrast even between people; between the few highly westernized, trousered, natives, educated in western universities, speaking western languages, and glorying in Beethoven, Mill, Marx or Einstein, and the great mass of their countrymen who live in quite other worlds. Capital and new ideas are not thinly diffused throughout the economy; they are highly concentrated at a number of points, from which they spread outwards (1954: 147-148).

Similarly, Hoselitz (1953: 197) argued that cities modeled after urban centers of the West displayed a "spirit different from that of countryside." Urbanization and what he referred to as 'generative cities', was vital to overcome 'traditionalism' and spur innovation, technological advancement and growth (Hoselitz 1955).

In other words, originating from islands of progress within a sea of tradition, modern elements are projected to diffuse "across the map, cascading down urban hierarchies, and funnelling along transport routes" (Peet and Hartwick 2015: 147). ${ }^{8}$ Political intervention by 'underdeveloped' countries adopting freer markets to allow capital inflows could further galvanize the process (Easterly 1999; Eggen and Roland 2013; Lewis 1954). ${ }^{9}$

The metaphor of the dual economy, and modernization theories more generally, systematically conceals how modern and traditional sectors/areas are entangled in symbiotic and asymmetric relationships (Bernstein 1971).

\section{Spatial blind spots: the politics and violence of modernization}

Modernization theory exhibits a notable 'spatial' blind spot. Its Eurocentrism deifies the global supremacy of Western mental models and institutions, but systematically turns a blind eye to how the 'rise of the West' has been shaped by global patterns of dispossession, resource transfers and unequal market relations. Rather than simply occurring through internal processes as implied by 'stages of growth' theories (Rostow 1960), 'Western modernization' took place progressively and violently, externalizing agricultural production to colonies. ${ }^{10}$ This inherent blind spot - as noted in particular, by dependency and world-system analysts (e.g. Frank 1979; Wallerstein 2004) - typifies a certain form of power exertion in the development project via depolitication: that is, "by constructing a universe of meaning in which the specific deficiencies that are to be rectified by development are portrayed as purely technical problems and the interventions through which this is to be done as purely technical solutions" (Nilsen 2016: 272). Rather than understanding

\footnotetext{
7 Diffusion in this context signifies the spread of 'modern elements' (i.e. institutions, technologies and culture/attitudes from regions of high concentration (predominantly global North and/ or urban centers) to regions of low concentration (predominantly the global South and/ or rural areas).

${ }^{8}$ Delacroix and Ragin highlight a particular modernization governmentality through which the state and urban elites disseminate "modern values and attitudes" via modern institutions such as the school and mass media (1978: 126).

${ }^{9}$ As Lewis (1954) pointed out, urbanization and urban based industries along with rural based commercial/industrial agriculture are both constituents of the modern sector.

${ }^{10}$ A similar feature of 'externalization' can be identified in the new green economy (see below) as companies and rich nations seek to 'green' their growth through various forms of environmental offsets in the global South.
} 
social impoverishment and/or environmental devastation as outcomes of specific power relations, such questions are 'rendered technical', and thus 'simultaneously rendered nonpolitical' (Li 2007: 7).

These underlying spatial and political dimensions of capitalist modernization were central themes in the work of Karl Polanyi. In his critique of liberal capitalism, Polanyi (1944) describes modernization understood as the move in Europe from preindustrial to industrial societies - as a process of gradual 'disembedding' and commodification. Drawing centrally on Marx's (1887) theorization of capitalism (Prudham 2013), Polanyi argued that this process relied on the decoupling of labor and land (nature) from the socio-ecological systems in which they are embedded. ${ }^{11}$ This included steps to mobilize land (e.g. via enclosure laws) alongside technological intensification of agriculture and in the process forming the 'surplus labor' force that Lewis (1954) referred to: "farming was business, and ...those who were poor must clear out" (Polanyi 1944: 192; Stroshane 1997). Referring to Jeremy Bentham who stated that the condition most favorable to (capitalist) modernization exists "when there are no entails, no unalienable endowments, no common lands, no right redemptions, no tithes", Polanyi stated that 'disembedding' processes were purposeful and strategic.

The enclosure laws and land consolidation measures in England in the $18^{\text {th }}$ and $19^{\text {th }}$ centuries were regarded by Polanyi as a "revolution of the rich against the poor" (1944: 37). To Marx (1887) this marked the original moment of 'primitive accumulation' -expropriation of producers from their means of production (labor formation) and the emergence of a capitalist class - in the history of capitalism. ${ }^{12}$ The system gradually expanded via resource appropriation in subtropical regions signifying the application of an industrial/agricultural division of labor on a world scale (Frank 1979; Friedman and McMichael 1989; Marx 1887; Polanyi 1944). ${ }^{13}$ This underscores the blind spots intrinsic to mainstream accounts of modernization: rather than being an internal, national and 'natural' process, it rests upon a global socio-ecological relationality with winners and losers. Harvey (2003) later introduced the concept of 'accumulation by dispossession' to describe accumulation as an ongoing process in the reproduction of capitalism.

Polanyi emphasized that complete 'disembeddedness' was a utopian mission. No society could absorb the complete socio-ecological destruction associated with the 'satanic mill' of unregulated capital. Hence, the perpetual pursuit of exchange-value would inevitably incite counter-forces - formal and informal social organizations and movements - pushing to re-embed the market in a system of social and environmental regulations. ${ }^{14}$ This 'double-movement', as Polanyi calls it, is in continuous tension and lies at the crux of capitalist development. To Harvey (2014) this dynamic symbolizes capitalism's elasticity and potential for expanded reproduction in the face of social and environmental pressures.

\section{Ecological blind spots and modernization today: from brown to green}

Ecological issues have been neglected in most conceptions of development and modernization. Arguably a hangover stemming from the Cartesian worldview, the ecological side-effects of capitalist modernization have been reduced to 'externalities' and thus shifted across the dualistic divide. However, these 'externalities' periodically strike back; as Patel and Moore (2017: 21) write: "...the modern world emerged

\footnotetext{
${ }^{11}$ This venture, Polanyi (1944: 188) stated, became manifest via "subjection of the surface of the earth of the planet to the needs of an industrial society."

12 Both Marx and Polanyi recognized 'primitive accumulation' as "the singular genesis for both the commodification of land and the commodification of labor" and thereby its foundational significance for the capitalist organization of society (Prudham 2013: 1579).

${ }^{13}$ Yet, Shivji (2008: 27-28) notes, Marx "saw the march of European capital into these continents, however brutal it was, a means by which the backward forms of production and society would be brought into the age of modern capitalism, and therefore, progressive."

${ }^{14}$ These would include not only the traditional working class resistance that is often linked with Marx (Stroshane 1997), but agrarian, environmental and labour movements more broadly (Prudham 2013). Polanyi (1944) emphasized that the countermovents' chances of resisting and reversing processes of commodification would depend on the classes and organizations' ability to win support outside their own membership and speak for society more generally.
} 
from systematic attempts to fix crises at the frontier, crises that resulted from human and extrahuman life inserting itself" into the calculus of production. Said differently, capitalist modernization evolves through frontiers, expanding into new spheres and spaces in response to externalities and in the process creating new sites and relations of power. To Harvey, frontiers appear as short-term 'fixes' to capital's internal contradictions $(1981,2001,2014)$. Externalities that strike back mobilize capital to develop new strategies for accumulation via technological or spatial fixes. This logic, in our view, is the raison d'être behind the green economy and is reflected in leading institutions' policy documents on green growth (the Organization for Economic Cooperation and Development (OECD) 2009; UNEP 2011a). ${ }^{15}$

By the 1970s (with 'limits to growth') and 1980s (with 'sustainable development'), the ecological question was on the global agenda. The environmental costs associated with development prompted calls for the incorporation of environmental issues in economic and development planning (Pearce, Markandya and Barbier, 1989). Yet, the ecological question garnered limited attention until the late 2000s (Tienhaara 2013). Intersecting crises in climatic and environmental systems along with food price increases and the global financial downturn, provoked increased comprehension among governments and civil society about the urgency to stake out a 'new path' that aligns the global economy with environmental issues. The emerging green economy framework (and the related concept of green growth) as conceptualized in a variety of policy documents by actors such as UNEP (2011b), World Bank (2012) and OECD (2009, 2011, 2012) - is understood as a new frontier; that is, environmental and climatic change is conceived as an opportunity rather than crisis - to create new zones of interaction between capital and various forms of nature. At this frontier, (green) economic activities promise triple-bottom lines - people, planet and profits - in a new 'enlightened capitalism' (White 2013).

In the context of the 'environmental turn' during the 1980s, new approaches emerged within environmental sociology around the concept of eco-modernization (see review by Mol and Spaargaren 2000). This reformist perspective generally views the ecological scarcity induced by modernization as a "design fault" (Spaargaren and Mol 1992: 329) and opportunity to innovate and devise new technologies in a 'greener' direction. Gleeson and Low (1998) summarize the three main tenets of eco-modernization as

1) the ecologization of production,

2) market and regulatory reforms that reflects ecological priorities, and

3) the 'greening' of social and corporate values and practices.

Eco-modernization assumes that ecological sustainability is well attuned with growth (by decoupling) and 'modernization' (York and Rosa 2003), and supporters believe firmly in "the self-corrective potential of capitalist modernization" (Gleeson and Low 1998: 165). Going further into capitalist modernization and industrialization is, in other words, not a problem, but a solution that "offers the best option for escaping from the global ecological challenge" (Spaargaren and Mol 1992; York and Rosa 2003: 273). From this view, ecomodernization emerges as the ultimate evolutionary stage of development in accordance with the environmental Kuznetz curve (Stern 2004). The implicit implication is that eco-modernization is something countries 'do' once reaching a certain threshold of affluence.

Hence, the eco-modernization discourse focuses on the global North and how to devise and deploy technological improvements to an already existing industrial sector. Consequently, its application beyond the global North has been negligible (Adams 2008). The Rio+20 green economy conception reflects to a great extent the same discursive trends as in eco-modernization. However, the green economy discourse is more global and explicitly incorporates (green) development in the global South.

\footnotetext{
${ }^{15}$ According to Brown et al. (2014: 246), the green growth agenda represents a 'new component' in the "broader economic liberalization agenda" of these institutions.
} 


\section{Green economy, development and green modernization}

According to UNEP (2011a: 16), the main rationale of the green economy is "to enable economic growth and investment, while increasing environmental quality and social inclusiveness." While these ideas cover many areas, the practical focus remains on technological and market-based solutions. Leading development institutions consider the green economy to embody the promise of a "new development paradigm" that paves the way for a "great, green technological transformation" (United Nations Department of Economic and Social Affairs (UNDESA) 2011: v). This new agenda appears to reassert development as modernization with a green profile: it is in this context we identify an emerging green modernization development discourse.

Influenced by the same Cartesian ontology, the green modernization development discourse advances green incarnations of dominant modernization narratives. Its focus is, in particular, on commodification and modernization of 'green' sectors, with resulting shifts in access to, and control over, natural resources in the global South (Bergius et al. 2018; Buseth 2017; UNEP 2011a). The conception of green modernization relative to eco-modernization - attempts to capture these dynamics, prompted in large part by a new institutional context of the green economy that insists on a combination of tha application of technology, continued productivity growth and private capital to set green development trajectories in motion (Bailey and Wilson 2009; OECD 2009, 2011; UNEP 2011a; World Economic Forum (WEF) 2010).

As Green (2015: 632) notes, the "current incarnation" of the growth and modernization agenda valorize, in particular, "private business as development catalyst." After the converging crises of the late 2000s, Green (2015: 630) writes, international development funding was reprioritized towards the private sector in support of "for profit-driven economic growth within a context of globalization." As Bergius et al. (2018) argue, this turn of aid and development towards the private sector can be seen as a key vehicle by which capital's spatial-fix to new resource frontiers is enabled in response to an accumulation crisis. In this context, 'green sectors' - for example agriculture, forestry or carbon/biodiversity offsets - have over the last decade become important outlets for (often aid-supported) private capital as part of a general cycle of 'material expansion' in contemporary capitalism (McKeon 2014; Kröger 2013, 2015; World Bank 2013). The growing capacity of the International Finance Corporation (IFC) and Development Finance Institutions (DFIs) since the financial crisis, whose primary aims are to incentivize and support private sector investments, is an important signifier of this private turn (Currey 2014; Kwakkenbos 2012). ${ }^{16}$

From the perspective of green modernization, the 'underdevelopment', 'traditionality' or 'backwardness' of countries in the global South tend to be implicitly expressed as an advantage in the form of 'untapped markets' or 'underutilized' land and natural resources that can be linked with the stock of capital, knowledge and technology accumulated in the global North. This would, in theory, allow developing countries the possibility of "tunneling through" the detour suggested by the environmental Kuznets curve in their quest for development and modernization (Adams 2008: 120). Renowned professor and development economist, Carlos Lopes, aptly sums up this perspective in a recent op-ed where he explains how Africa "can avoid the polluting stage of industrialization" by making an "impala-like leap into a green, industrial economy" (Lopes 2017). However, absent from the green modernization discourse are questions of power, rights and distribution, hence rendering technical (Li 2007) challenges and processes which are inherently political.

These trends are visible, in particular, in discussions around contemporary food and agricultural development. Within the wider green economy context of the last decade a number of interconnected largescale agricultural initiatives have brought together a diverse set of actors - philanthrocapitalists, donors, governments, corporations and agricultural research centers - that promise poverty and food insecurity reduction alongside environmental protection and to achieve a new green revolution in Africa. Both in their framing and proposed solutions, these initiatives amalgamates under repacked and green versions of modernization.

\footnotetext{
${ }^{16}$ Kwakkenbos (2012) reports that cash flows to European DFIs between 2006 and 2010 increased the funds' investment portfolios by 190 percent. Similarly, the IFC accounted for 35 percent of total commitments by the World Bank group in 2013 as compared to 18 percent and and 13 percent in 2009 and 2000, respectively (Currey 2014).
} 


\section{The new green revolution in Africa as green modernization}

It is "Africa's turn", a 2006 text from the Rockefeller Foundation narrates, to reap the benefits of the advanced agricultural science associated with the original Green Revolution. However, the foundation continues, more than a "triumph of unfettered science", the original Green Revolution was,

at its origins, a strategic act of philanthropy, enlisting experts, government, and ultimately local scholars and farmers in a carefully wrought partnership that grew geometrically-and deliberately - over many years. Science, donations, and market forces all played an indispensable part; but all were guided, in the first instance, by a philanthropic plan (Rockefeller Foundation 2006: 4).

That plan, which materialized first in Mexico, and then further into Latin-America and Asia, involved funding research for industrial agriculture and the introduction of high-yielding variteties of staple grains, agro-chemical inputs and irrigation that resulted in significant aggregate yield increases. These transformations have been widely celebrated as the triumph of science over the Malthusian trap (Malthus 1998 [1798]) and culminated in the award of the Nobel Peace Prize in 1970 to the Revolution's most prominent scientist, Norman Borlaug.

However, while yields increased, the wider social and environmental implications of the Green Revolution are much more intricate than the win-world narrative presented by the Rockefeller Foundation (Eddens 2017; Freebairn 1995; Holt-Giménez and Altieri 2012; Patel 2012; Pimentel and Pimentel 1990). ${ }^{17}$ Nonetheless, after lauding the philanthropic powers that wheeled the original Green Revolution in motion, the Foundation continues in its 2006 text by declaring that "a similarly decisive initiative from philanthropy [...] could well spark a new Green Revolution, this time for Africa" (2006: 4) ${ }^{18}$ In partnership with the Bill and Melinda Gates Foundation, the Rockefeller Foundation went on to launch the Alliance for a Green Revolution in Africa (AGRA) - registered as an NGO and a key actor in the institutional framework that makes up the new green revolution (Daño 2007). ${ }^{19}$

Contemporary political economies of food and agriculture differ from those in 1960s and 1970s. Whereas the original Green Revolution arose on the premise of strong state support, the milieu in which the new green revolution for Africa expands is characterized by the spread since the 1980s of neoliberal political agendas and market-based approaches that have put smallholders under severe constraints (Dawson et al. 2016). The role of the state in the new green revolution has, in other words, shifted towards becoming primarily a facilitator of conducive business environments to allow the private sector and large agribusinesses to take on a leading role through investments (Moseley 2017). Indeed, this asserts the prevailing private turn of aid in which businesses and markets are considered the principal 'development catalysts' in the spaces opened up by neoliberal structural adjustment policies. In this context, the leading view among proponents of a new green revolution is that rural transformation and poverty alleviation will be private sector led and achieved indirectly "through trickle-down effects from an agricultural boom" (Dawson et al. 2016: 205). As such, the new green revolution extends a productivist notion that sees hunger predominantly as a supply-side issue, rather than a problem of access to resources (Moseley 2017; Lappé 2012).

The term 'Green Revolution' was first coined by USAID administrator William Gaud in 1968 (Gaud 1968). As Spitz ([1987] 2011: 42) writes: "'Green', of course, was implicitly opposed to 'red' and was

\footnotetext{
${ }^{17}$ In a review of more than 300 articles, Freebairn (1995) found that in more than $80 \%$ of the sample both interfarm and interregional inequality increased. Moreover, removing China from the hunger statistics, the number of hungry people increased by more than 11 percent, thus suggesting that the growing food supplies were unaccompanied by growing food access (Lappé and Collins 2015).

18 This idea of recreating the 'triumphant act' of philanthropy is a good example of some of the discursive powers at work in the new green revolution and contemporary privatization of development more generally (Green 2015; Moseley 2017).

${ }^{19}$ See Daño (2007) for details on the actors behind the Green Revolution in Africa.
} 
signaling, like a flag, that social reform was not necessary, since technical means in agriculture (evoked by 'green') alone were supposed to solve the problem of hunger." The 'green' flag in the new green revolution has an expanded meaning and also incorporates ecological concerns. Already in 1997, Gordon Conway, then newly elected president of the Rockefeller Foundation, called for a "doubly green revolution" (Conway 1997), essentially making the case for an "ecologically-sound replay" of the first (Patel 2012: 37). Ismail Seregeldin, then head of CGIAR, went even further, calling for a "thrice green revolution: green for productivity, green for environmental sustainability, and green for increased income" (Holt-Giménez 2006: 156). This expanded 'greeness' in the new green revolution answers to the triple bottom line advanced under the green economy and arguably opens up new 'green' spaces for accumulation (for example via climate-smart agriculture (Newell and Taylor 2018) as part of what Friedman (2005) has conceptualized as the corporate-environmental food regime. ${ }^{20}$

Whether portrayed as 'doubly green' or 'thrice green', the new green revolution represents an eloquent example of 'green modernization'. Informed and justified by neo-Malthusian thinking, its stated objective is development through poverty reduction and food security, it has a strong green rhetoric and it is private sector led and capital/techno-centered constituting a wide array of public-private investment platforms. In the light of contemporary environmental and climatic challenges, the new green revolution has an expanded purpose, but the core remains unchanged. Within the context of the emerging green modernization discourse, the new green revolution, we argue, evolves at the interface of three interlinked narratives around technology and productivism, 'surplus nature' and capital deficits, and population trends. To these we now turn to illustrate how 'modernization' is reinforced in international aid and development under the banner of the 'green economy'.

\section{Technology, 'productivism' and 'sustainable intensification': Feeding the world while saving nature}

The new green revolution is infused by a steadfast belief in the power of science and technology to 'feed the world' in an era of climate change (Collier 2008; Rockefeller Foundation 2006; WEF 2018). ${ }^{21}$ There is a sense of optimistic evolutionism to this belief; target countries are destined to climb the development ladder by adopting technocratic solutions to their 'under-development' - a condition which is considered to contribute to unsustainable practices. Only by getting the 'right policies' in place to support the diffusion of the 'right technologies' to the 'right farmers' can African countries generate momentum for development and break the fetters of the past (see Figure 2 below) (Bushell 2014). This is underpinned by assertion using a particular blend of Malthusian and Ricardian inspired narratives of absolute and relative scarcity in the tripartite relationship between food production, population growth and the environment (Dawson et al. 2016; Scoones et al. 2014). ${ }^{22}$

In particular, normative interpretations of the ' 9 billion people by 2050' challenge - the assumed need to double food production - have been widely and strategically adopted as a discursive device by institutions and businesses promoting a new green revolution (Bushell 2014; Rockefeller Foundation 2006; Tomlinson 2013). The imperative to double food production to avoid a potential Malthusian downfall has given renewed impetus to a politics of productivism among governments, development institutions and corporations in the approach to food security (Horlings and Marsden 2011; McKeon 2015; Tilzey 2018). Through the 'productivist' lens, smallholders are found lacking in terms of scientific knowledge and 'yield gaps' which can

\footnotetext{
${ }^{20}$ This regime, as described by Friedman, is undergirded by a "new round of accumulation...in the agrofood sector, based on selective appropriation of demands by environmental movements" (2005: 229).

${ }^{21}$ As Collier, an influential author and protagonist of large-scale commercial agriculture, argues: "First, contrary to the romantics, the world needs more commercial agriculture, not less...Second, and again contrary to the romantics, the world needs more science..." (2008: 68).

${ }^{22}$ Malthusian notions of absolute scarcity see scarcity to emerge as a result of the inevitable contradiction between growing populations and the (in)ability of "earth to produce subsistence for man", while relative scarcity emphasizes that scarcity is not absolute, but can be overcome through technological innovation and more efficient allocation of resources (Scoones et al. 2014).
} 
be resolved via gradual adoption of the right technologies - developed and devised by large-scale agribusiness corporations - in the progress towards becoming 'advanced' farmers motorizing development (see Figure 2). Bill Gates sums up this approach thus:

The metrics here are pretty simple. About three-quarters of the poor who live on these farms need greater productivity, and if they get that productivity we'll see the benefits in income, we'll see it in health, we'll see it in the percentage of their kids who are going off to school. These are incredibly measurable things. The great thing about agriculture is that once you get a bootstrap - once you get the right seeds and information - a lot of it can be left to the marketplace. (Gates 2013 in McKeon 2015: 72)

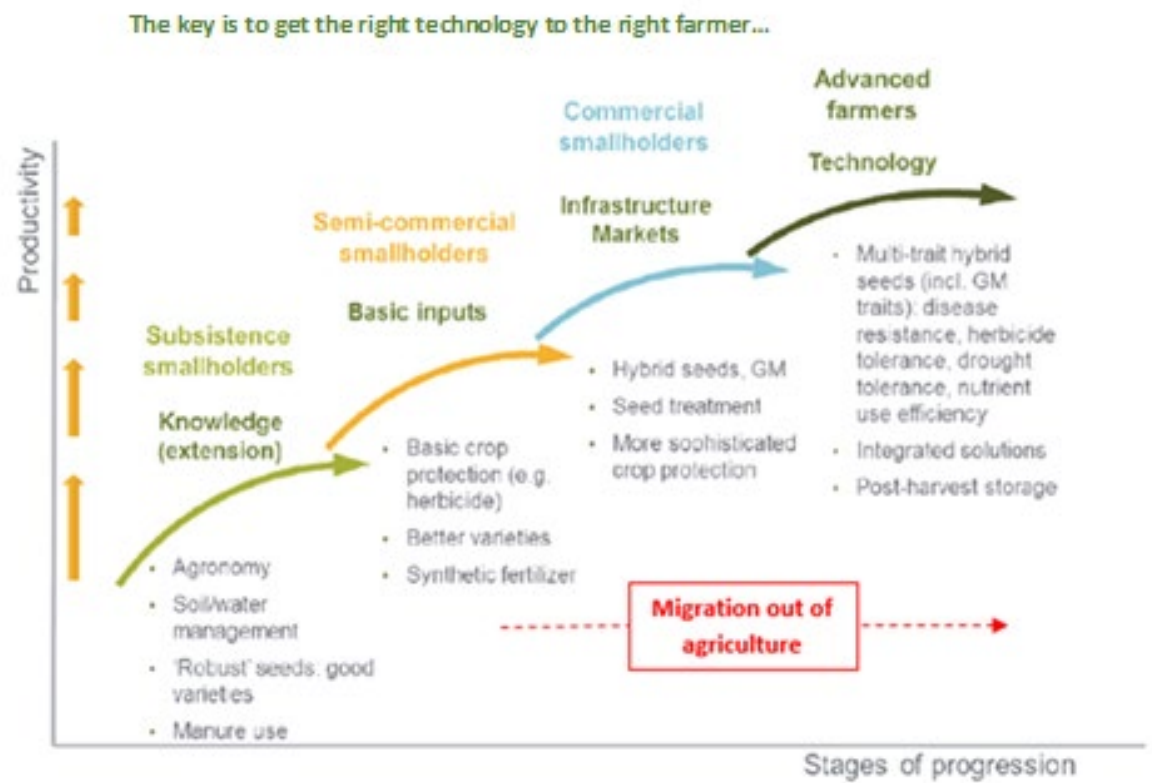

Figure 2: Syngenta's 'Stages of Progression' for farmers. Modified from Bushell (2014) and Zhou (2010).

While 'productivism' has been the dominating approach to global food security in the post-war context of the original Green Revolution (Horlings and Marsden 2011), the new green revolution is strongly influenced by environmental and climatic stresses. Thus, contemporary notions of productivism develop within the wider frame of the green economy via vaguely defined, overlapping and interchangeably used concepts such as 'climate-smart agriculture' and/ or 'sustainable intensification' (McKeon 2015; Newell and Taylor 2018; Perfecto, Vandermeer and Wright 2009; The Royal Society 2009; Tilzey 2018; Tittonell 2014; Westengen et al., 2017; WEF 2010).

Advocates of the new green revolution in Africa particularly emphasize the Malthusian dilemma - that agricultural growth to date has come at the expense of forested land - and that more intensive (usually branded 'climate-smart') farming practices can address productivity (food security), climate and biodiversity challenges (Dawson et al. 2016; Taylor 2018; Yara 2015). In short, according to dominant framings, this 
entails producing more food from less land and not necessarily less inputs (Westengen et al. 2017). ${ }^{23}$ Hence, 'smart' and 'intensified' farming should make use of all available modern technology - including chemical fertilizers and latest advancements in genetic modification - to control and 'outsmart' nature (Borras $\mathrm{Jr}$ and Franco 2018; ETC Group 2015; McKeon 2015; Tittonell 2014). The fertilizer industry in particular has been at the forefront of the multiple and interlinked agricultural initiatives currently being rolled out under the new green revolution as climate-smart. Spearheaded by the Norwegian, partly government owned, fertilizer giant Yara ${ }^{24}$ the industry upholds fertilizers as the 'smart' link between intensification and sustainability. Consequently, the industry is "pleased with the new and aptly coined term 'sustainable intensification"' (International Fertilizer Association (IFA) 2012: 5) and "fully supports and implements the concept" (Yara n.d.-c). This agro-industrial view of intensification stands in contrast to the classic Boserupian model - also referred to as autonomous intensification - which predicates agricultural intensification occurring via population growth and subsequently more labor intensive, rather than capital intensive, production techniques (Boserup 1965; Tiffen, Mortimore and Gichuki 1994).

To Yara (2015: 4), intensified and "modernized, high-yielding farming" is smart in the sense that it is the only way to enhance productivity to feed 9 billion and simultaneously prevent "an area the size of most of Western Europe [...] [to] be converted to farmland - releasing massive amounts of greenhouse gases" (2015: 12) and leading to "loss of biodiversity and ecosystem services" (2015: 4). ${ }^{25}$ Indeed, these rhetorics - the so called Borlaug hypothesis (Angelsen and Kaimowitz 2001a) - epitomize the mainstream discourse around climate-smart and intensified agriculture and similar initiatives under the new green revolution.

The narrative around 'sustainable intensification' - referred to as an oxymoron by Marsden (2010) has been strongly challenged and critiqued by both environmental organizations and academics (e.g. Collins and Kirtana 2012; Kremen 2015; Perfecto and Vandermeer 2010; Struik et al. 2014; Tittonell 2014). Three key interlinked facets of this debate are important to our purpose. First, by rendering questions around sustainable agriculture and global food security as predominantly technical, it disguises underlying political economic relations of power - who wins and loses and how (Bernstein 2010) - associated with input market and technology upscaling (Clapp et al. 2018). Yet, occasional references to 'land mobility' (Gates Foundation 2008 in Patel 2012) and 'migration out of agriculture' (Zhou 2010) implicitly indicate a future trajectory of dispossession of those unable to transition to the higher stages of the modernization ladder (see below). Inherent to this political economy of sustainable intensification/climate smart agriculture, is the tendency to contrast extensive 'low input-low productivity' agriculture in the global South ('underdeveloped') with intensive 'high input-high productivity' in the global North ('developed'), while disregarding how production and consumption patterns in the latter lay claim on increasing areas of land in the former.

Second, the "article of faith" in development and environmental circles that automatically link agricultural intensification with land sparing, is not given (Angelsen and Kaimowitz 2001b: 89). Although resulting from a complex set of factors, there is a risk that intensification via capital-intensive technological change promotes deforestation as more well-off farmers are incentivized to expand production, while

\footnotetext{
${ }^{23}$ Given that chemical input use in Africa remains at very low level, Tittonell (2014) points out, there is no clear connection between goals to increase the use of fertilizers under the green revolution and aims of producing more with less.

${ }^{24}$ According to Yara (n.d.-b), the company initiated the African Green Revolution Conference (AGRC) - the predecessor of the African Green Revolution Forum (AGRF) - in 2006. Yara (n.d.-a) states that "several partnerships have been initiated after the conferences", of which "Yara's projects include two agricultural growth corridors in Tanzania and Mozambique" described as 'green corridors' to exemplify how green growth principles can be introduced" in agriculture.

${ }^{25}$ Elsewhere, Yara contrasts its own approach, referred to as 'productive farming', with organic farming which they claim would lead to lower productivity and therefore increased deforestation. However, recent research on diversified and agroecological farming systems indicate negligible differences in productivity per land unit (Ponisio et al. 2015).
} 
accumulation by dispossession pushes less resourced farmers to expand farmland into forests (Angelsen and Kaimowitz 2001a; Angelsen and Kaimowitz 2001b; Perfecto et al. 2009). ${ }^{26}$

Lastly, the intensification agenda reinforce the ontological dualism inherent to modernization discourses in the way the world is sub-divided into distinct landscapes for 'nature' (biodiversity and carbon sequestration) and landscapes for production to 'feed the world.' This dualism reveals underlying power structures in the workings of a contemporary corporate-environmental food regime that suggests a trade-off between technology-driven productivity, biodiversity and climate change mitigation. Indeed, this dualist worldview enables strategic partnerships around shared concerns between agribusiness corporations and mainstream conservation oriented NGOs (Holt-Giménez and Shattuck 2011; Newell and Taylor 2018), ${ }^{27}$ while disregarding alternative conceptions that see agroecological matrixes as key repositories for both production and biodiversity (Perfecto and Vandermeer 2010).

Under the green economy an opportune moment has arised for agribusiness corporations to rebrand their product lines under epithets like 'climate-smart' and 'feed the world' to capitalize on new market opportunities. As Clapp et al. (2018: 5) have recently pointed out, "many of these strategies, packaged as solutions to climate change, are being skillfully used to open up new commodity frontiers", while obscuring how they are girded by history, politics and power. What is new at the current conjuncture is not the link between technology and intensified agricultural production, but rather the adoption and promotion of green narratives around already existing technologies to recast the modernization trope as 'green.' Similar processes have been discussed as 'greenwashing' or 'grabbing green' (Buseth, 2017; Corson et al. 2013). In the language of Lewis' (1954) dual economy, the key feature here is the ostensible low productivity and environmentally unsustainable nature of 'traditional' farming relative to 'modern' or 'advanced' practices, which signify overall social, economic and ecological losses. Eliminating these losses and thus achieving progress - "feed the world and protect the planet" (Yara n.d.-a) - is possible if foreign public and private capital is mobilized to 'fructify' Africa's 'underutilized' resources (UNEP 2011a).

\section{'Surplus nature' and capital deficits: the role of capital in the green modernization discourse}

"Sub-Saharan African agriculture is underdeveloped. Its transformation from subsistence farming to modern, commercial agribusiness represents a massive long-term opportunity, especially considering Africa's wealth of natural resources" (AgDevCo 2017: 4). ${ }^{28}$ This quote summarizes a common perspective on the current state of rural Africa: It holds an abundance of underused nature (including labor), which, if coupled with accumulated global capital and technology, represents an opportunity for both business and sustainable development.

The World Bank epitomizes this view aptly in its Growing Africa - unlocking the potential of agribusiness' report (2013). Pointing towards a peak in global yields of major staple crops due to "the exhaustion of Green Revolution technology, a slowdown in research and development (R\&D) spending in many countries, and increasing land degradation and water scarcity", combined with future uncertainties around climate change, it predicts that "prices will be higher and more volatile relative to the past decade" (World Bank 2013: 15). In this context the World Bank (2013: 17) sees great potential for agribusiness expansion in Africa relative to Asia, which "faces an acute scarcity of land and water." Africa, however, "has an abundance of both" (2013: 17) for the production of food and agricultural exports - including sugar, palm

\footnotetext{
${ }^{26}$ This is not to dispute that agricultural growth in, for example, Africa in recent decades has been accompanied by extending cultivated areas (Evenson and Gollin 2003), but rather to problematize the air of sophistry around the simplified cause and effect relationship in agricultural intensification.

${ }^{27}$ This feeds into what Logan and Wekerle (2008) coined the 'neoliberalization of environmental governance' in which the role of NGOs have transformed from being watchdogs to 'partners' with key industry actors.

28 AgDevCo co-led the development of an 'investment blueprint' for Tanzania's main green revolution initiative, SAGCOT, in 2011, and played an even bigger role in the development of the Beira Agricultural Growth Corridor (BAGC) in Mozambique from 2010 onwards. The company was established in 2009 with significant support, in particular, from the Norwegian government. Other key supporters include the Rockefeller Foundation and the UK's DfID.
} 
oil and biofuels. Export commodity production, it notes, "gives a clear advantage to African producers with plentiful low-cost labor and/or land" (2013: 15-16). Hence, from the perspective of global capital, the "time has come for African agriculture. Southeast Asia has become crowded, competitive, and expensive for doing agribusiness, chipping away at profit margins. We see higher profit potential in Africa for exports - and for domestic sales" (2013: 16).

The many interlinked initiatives currently proliferating across Africa under the umbrella of the new green revolution ought to be understood, at least partially, from this perspective: as a spatial-fix for global agribusiness capital to falling profit margins (Harvey 2014). Indeed, as noted by the World Bank (2013), Africa has become the 'final frontier' for agribusiness corporations, which see great potential in the ostensible cheap nature/cheap labor nexus of the continent (Patel and Moore 2017).

The wide array of public-private investment platforms under the new green revolution are essentially framed through the vision of these agribusiness actors wishing to create markets and demand for their products. As Svein Tore Holsether, the CEO of Yara, states: "Yara realized early on in our operations in Africa that the international private sector cannot simply serve the agribusiness market in Africa; it must be part of creating that market" (WEF 2016: 12). That is why Yara took on a leading role in, for example, establishing the African Agricultural Growth Corridor initiatives to exemplify, in their own words, "how green growth principles can be introduced" in agriculture (Bergius 2014; Yara n.d.-a). In this context of expanding agribusiness frontiers, private capital is held forward by donors, governments and corporations as the main limiting factor to green development and modernization. There seems hardly to be any limit to the number of billions of dollars that have been pledged in investments under the various new green revolution initiatives for the development, deployment and distribution of (green) agricultural technologies. To ensure the smooth movement of this capital and linking it up with the ostensible dormant potential contained in Africa's lands, governments' roles are to create business-enabling environments.

'Enabling' environments are thought to create the conditions necessary to allow space for the private sector to drive development efforts. The World Bank promotes and incentivizes this through its annual Enabling the business of agriculture (EBA) reports, which ranks countries according to their attractiveness for agribusiness investments. The higher the EBA score a country receives, the more competitive and enabling it is for capital investments to address problems of hunger and poverty. Framed in the language of 'modernization', global South countries at the lower end are found to be "lagging behind" their better performing counterparts - mostly countries from the global North - having "less than half of the regulatory good practices promoted by EBA" (World Bank 2017: 7). As a consequence, donor support under G8's New Alliance for Food Security and Nutrition, a key initiative of the new green revolution, is tied to EBA linked conditionalities. Hence, countries that participates in the New Alliance scheme committed in their framework agreements to undertake a number of policy changes to liberalize regulations concerning land, seeds and other agro-inputs to incentivize agribusiness investments.

Integral to the private and 'green' turn in agricultural development financing is the proposed introduction of agricultural carbon markets via 'climate-smart' production practices. Smallholder farmers tend to be presented within a narrative that makes them beneficiaries of such markets (Newell and Taylor 2018). As Syngenta, for example, states: "The carbon market offers potential opportunities for farmers to benefit from payments for ecosystems services and agricultural and land use practices that sequester or use carbon efficiently" (Zhou 2010: 2). While denounced by many civil society organizations - including La Via Campesina - for lacking precision and 'greenwashing' industrial agriculture (The Ecologist 2015), Newell and Taylor argue that "dominant agribusiness actors [...] use CSA [climate smart agriculture] to advance their preferred technologies and strategies as well as seek to re-package them in ways which access new financial and revenue streams associated with carbon markets and the 'bio' or 'green economy'" (2018: 12).

The relocation of agribusiness capital to the 'final frontier' (World Bank 2013) under the new green revolution is arguably part and parcel of a contemporary epoch of material expansion in capitalism. In the context of the green economy this happens by ascription to an emerging green modernization discourse that seeks to 'climate smartify' what are essentially long-standing approaches to food and agricultural production by 'grabbing green' (Buseth 2017). A central aspect of this discourse is the construction and promotion of a 
narrative of imbalance between 'surplus nature' and capital/technology that needs to be rectified to ensure a 'green' development trajectory. However, this narrative often appears alongside contradicting neo-Malthusian perspectives on population growth and environmental degradation (Benjaminsen and Svarstad 2017).

\section{Mobility of land, people and 'stages of progression'}

Population trends are inextricably linked to the emerging green modernization discourse. Such trends are important both as drivers (population growth) behind green transitions and as integrated solutions to social and environmental challenges (agricultural outmigration and urbanization). The gradual disappearance of peasantries in the West - a trajectory of urban-based modernization to which a recent Ecomodernist manifesto explicitly subscribes (Asafu-Adjaye et al. 2015) - allowed modernization theorists to define the absence of peasants as a key signifier for development. As McMichael (2012: 8) notes, "a logical extrapolation (if not historical analysis) would therefore be to define peasant cultures elsewhere as remnants of 'Traditional Society"' and thus "destined to disappear, whether because of urban gravitational pull, green revolution technologies, eviction by land grabs, or unequal competition from First World agribusiness."

In other words, as modernization cascades, an implicit long-term notion involves the substitution of (some) rural peoples living from the land with capital and technology to facilitate outmigration from agriculture. In the neoliberal vocabulary of the new green revolution - where land is to be treated as a fungible economic asset - this process tends to be depoliticized as 'land mobility.' A 2008 unpublished summary of the Gates Foundation's agricultural development strategy elucidates this vision of rural transformation: it necessitates "market-oriented farmers operating profitable farms that generate enough income to sustain their rise out of poverty. Over time, this will require some degree of land mobility and a lower percentage of total employment involved in direct agricultural production" (Gates Foundation 2008 in AgraWatch 2011). Of course, the mobile component here is not the land itself, but rather labor: the people working it.

Similar visions of development are shared by many African elites and policymakers. The Tanzanian Minister of Agriculture, for example, was recently quoted stating that "A farmer who sees that they wouldn't follow modern farming procedures shown by extension officers should quit and pave way for other farmers who are ready to do so" (The Guardian 2017).

The theory of change invoked by this conception of 'land mobility' is akin to Syngenta's vision of 'good growth' (see Figure 2 above). Bearing striking resemblances to Rostow's stages of growth theory, Syngenta's 'good growth plan' - alternatively "stages of agricultural intensification" (Zhou 2010: 4) - explicitly posits agrarian change as traversing through a series of stages where the final step insinuates highly capital and technology-intensive agriculture dominated by an emerging base of what Syngenta conceptualize as 'advanced farmers.'

The modern, business-oriented and advanced farmer represents the antithesis of the unsustainable and 'backward' condition of African agriculture at present (Scoones et al. 2014). As the Syngenta model and similar calls for land mobility predict, this 'good growth' towards modernization is not for everyone and those farmers unable to take the next step - from agriculture to agribusiness (AGRA 2017b) - are projected to 'migrate out of agriculture', although it is not clear to what and where (Li 2011). To Akinwumi Adesina, former associate director of food security at the Rockefeller Foundation, winner of the 2017 World Food Prize and current president of the African Development Bank, this could in theory realize his prediction, that "Africa's agricultural take-off will make billionaires from poor men's fields"(AGRA 2017a). ${ }^{29}$ Perhaps these prospective billionaires are the supreme signifiers of the white-collar agribusiness managers Swedish company Agro EcoEnergy imagined would emerge as a result of their large-scale investment in Tanzania (Figure 3). Nevertheless, the notion of 'land mobility' - allowing land to 'move' to supposedly more efficient, sustainable and business-oriented producers, while reducing the overall number of people involved in

${ }^{29}$ While the prediction about Africa's future billionaires stems from Adesina, the exact wording of this quote is from AGRA's head of policy and advocacy (AGRA 2017a). 
agriculture - "lies at the heart of the modernization narrative" (Bergius et al. 2018: 4) and is supported by influential actors, including the World Bank, as a decisive factor to "move upwards" in the "value-chain of countries" (Akram-Lodhi 2008; McMichael 2009; World Bank 2007). ${ }^{30}$

However, following Polanyi's (1944) reminder that a 'disembedded economy' was not the result of some natural force, land mobility does require land to be mobilized. Several land use planning and property formalization schemes with this intention are currently underway in Africa as part of the wider institutional infrastructure of the new green revolution. ${ }^{31}$ Land use planning enables land mobility and consolidation (Walwa 2017) and is a precondition for commercial estates - Lewis's islands of progress (1954) - to be established, "since only once tenure rights are fully clarified shall the investor be assured that its title is secure" (De Schutter 2015: 24; Greco 2016). ${ }^{32}$ Reporting from an agricultural frontier area in Tanzania, Greco (2016) argues that the region's status as a high-potential zone for agribusiness investments has incited donors to fund a land planning and formalization program, with a core aim is to publish a database with land available for investments. Further, she writes, "the speedy implementation of [land-use plans] in Kilombero District seems to indicate that they are more likely to be sponsored when strong corporate interests are at play", such as the G8's New Alliance for Food Security and Nutrition, "which require rapid and effective formalization of land property" (Greco 2016: 35). ${ }^{33}$

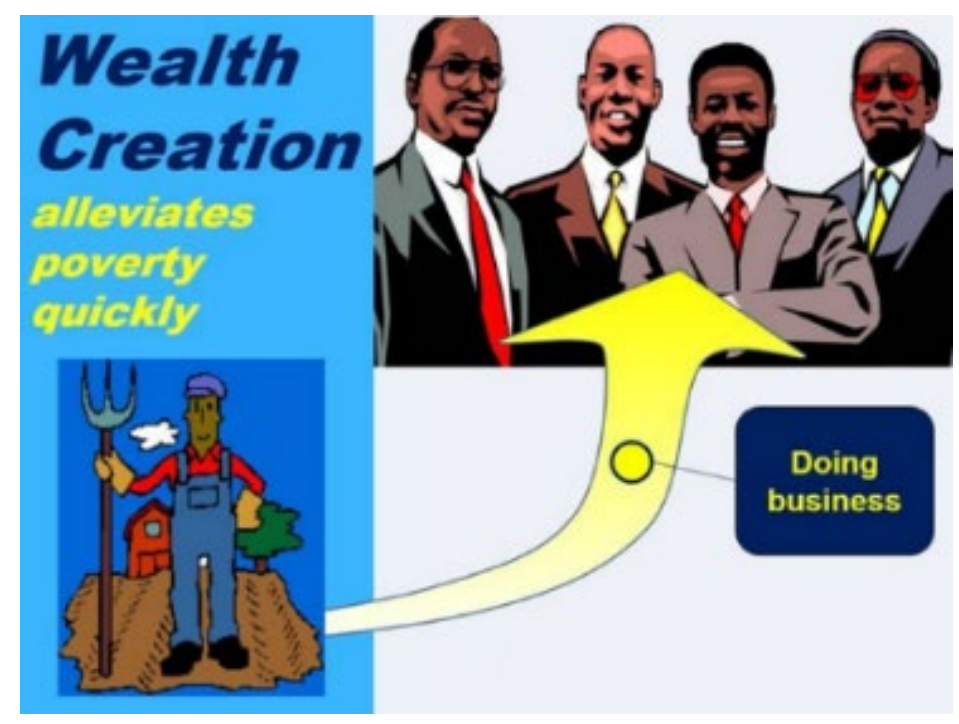

Figure 3: The future farmers of Africa? Swedish company Agro EcoEnergy's illustration of how large-scale investments will catalyze economic growth and turn small-scale farmers into agribusiness managers (Agro Eco Energy n.d.).

The condition obstinately regarded as most favorable to agricultural modernization, as Jeremy Bentham once proposed (in Polanyi 1944), exists when land is alienable and 'mobile.' Although leading

\footnotetext{
${ }^{30}$ As stated by former Norwegian Minister of Foreign Affairs, Børge Brende, during a discussion on the Sustainable Development Goals at the Norwegian University of Life Sciences in August, 2017.

31 As part of its Cooperation Framework to support the New Alliance for Food Security and Nutrition the Tanzanian government, for example, committed to demarcating all village land and completing Village Land Use Plans (VLUP) in $40 \%$ of the villages within its Southern Agricultural Growth Corridor area (New Alliance 2012).

32 This is a double-mcedged sword, as secure land tenure plays a vital role for smallholder farmers. What matters is to what extent smallholder's interests relative to agribusiness capital are reflected in these processes.

${ }^{33}$ See also Bergius (2016).
} 
proponents of agricultural modernization appear to put more emphasis on the importance of smallholders than they have over the last few decades, mainstream policy discourse remains infused by the idea that the long term vision of a 'thrice green revolution' are better addressed by a gradual move towards capital and technological intensification and larger scales in production. This view is manifested, in particular, by the substantial increase in farmland investments spurred by the converging crises of the mid 2000s (Borras Jr. et al. 2011; Hall, Scoones and Tsikata 2017). The displacement and injustice occurring in the wake of many of these investments, whether for or food, fuel or carbon-sinking, represent the politicized side of the 'land mobility' coin, and, as Harvey (2014: 55) posits, a global "politics of accumulation by dispossession run riot in ways that even Polanyi could not have imagined."

Flagged by a depoliticized green language of climate smartness, sustainable intensification and land mobility, public and corporate interests subscribe to a resilient and linear historical narrative of modernization that risks reinforcing a pattern of rural depopulation (Borras and Franco 2018; Davis 2006; Engström and Hajdu 2018; Li 2010). ${ }^{34}$ Registered in the long-standing dualist ontology undergirding this narrative, the emerging green modernization discourse would perceive such trends as progressive change. Indeed, modernization is simply "not possible in a subsistence agrarian economy" (Asafu-Adjaye et al. 2015: 13). The ultimate stage of agricultural intensification is presumed to allow for less people being directly involved in agricultural production, and thereby unleashing the 'unlimited supplies of labor' from the countryside (Lewis 1954). This is a path to green modernization that will ultimately, it is assumed, reduce pressures on 'nature.'

\section{Concluding remarks}

Upon receiving the World Food Prize in 2017, Akinwumi Adesina proclaimed his pride of being a "disciple of Norman Borlaug to preach the new "agriculture gospel" across Africa." In Adesina's words, the

...new agriculture gospel is simple: to lift millions of people out of poverty, agriculture must become a business. For in agriculture as a business lies the hope of economic prosperity for Africa [...]. Every time I pass through rural parts of African countries - where the agriculture engine is or should be unlocked - I see nothing but wasting potential. They sit on $65 \%$ of the uncultivated arable land left to feed the world, but can barely feed themselves. They hear of rich farmers in Europe and America and wonder why they themselves languish in poverty. Certainly life must be better than this. Why have we forgotten them? (Adesina 2017)

Adesina's analysis is indicative of the modernization discourse that epitomizes the new green revolution for Africa. Against a background of a present state of misery relative to the richness of industrial agriculturalists in the global North, a new green revolution premised on a combination of agribusiness capital and technology promises to unleash the dormant development potential currently 'wasted' in Africa's lands. While this trope of modernization is long-standing, we have argued in this article that the new green revolution and its emergence within a contemporary green economy feeds into an emerging green modernization development discourse.

'Greening' development and growth under presumptions of realizing a triple bottom line have been at the core of international politics since the Rio+20 conference in 2012. While in the global North this mainly entails ecologization of an already existing industrial sector (eco-modernization), the trend in the global South is making investments in and modernization of 'green sectors' to make the development path 'green' from the onset. We have argued in the case of the latter that the post-Rio+20 green economy context has revitalized green versions of classic modernization thinking in development. This trend is visible, in particular, in the agricultural sector where proponents of a new green revolution in Africa increasingly avow green narratives

\footnotetext{
${ }^{34}$ As McMichael (2009: 239) writes, "the Rockefeller/Alliance for a Green Revolution in Africa (AGRA) embraces this model, combining with other multilateral and corporate funds generated at the Rome summit to restructure African farming..."
} 
around a deeply rooted techno-scientific paradigm of development, modernization and progress. More laden political questions of power, rights and distribution, remain muted (Chandra, McNamara and Dargusch 2017).

We have pointed towards three interlinked components of the new green revolution for Africa that exemplify this emerging green modernization discourse. First, under new green brands such as 'climate smart agriculture' and 'sustainable intensification' it extends an unshaken belief in technological fixes to alleviate poverty, feed the world and protect the environment. Second, it furthers a legitimizing narrative of imbalance between 'surplus nature' and capital that needs to be remedied to ensure 'green' growth and development. And lastly, it rests upon an idea of 'land mobility', which in the long run envisions a trajectory of agrarian change that allows for less people being involved in agricultural production.

To conclude, our discussion of the new green revolution as an example of green modernization illustrates the ways in which discursive powers expressed through the green economy and the green growth paradigm influence policies implemented in practice. These capital-led initiatives garner little consensus among smallholders and their organizations. Across the world - including in Sub-Saharan Africa - alternative (green) visions of agricultural development exists among smallholders and organizations such as for example La Via Campesina. Their alternatives propose radically different agrarian futures seeking to (re)connect humans with nature via agroecology and food sovereignty.

\section{References}

Adams, W.M. 2008. Green development: environment and sustainability in a developing world. London: Routledge.

Adesina, A. 2017. Africa's pathway out of poverty. Dr. Akinwumi A. Adesina, President of the African Development Bank, World Food Prize laureate luncheon, October 20, 2017, in Des Moines, Iowa. AfDB. https://www.afdb.org/en/news-and-events/africas-pathway-out-of-poverty-by-dr-akinwumi-aadesina-president-of-the-african-development-bank-world-food-prize-laureate-luncheon-october-202017-in-des-moines-iowa-17468/ [accessed May 3 2018]

AgDevCo. 2017. Building African agribusiness for impact. London: AgDevCo.

AGRA. 2017a. Africa's agric take-off to make billionaires, from 'poor men's fields'. AGRA. https://agra.org/news/africas-agric-take-off-to-make-billionaires-from-poor-mens-fields/ [accessed March 12018 ]

AGRA. 2017b. Opinion: the future of farming in Africa is not agriculture but agribusiness. AGRA. https://agra.org/news/opinion-the-future-of-farming-in-africa-is-not-agriculture-but-agribusiness/ [accessed February 2 2018]

AgraWatch. 2011. Footloose farmers. AgraWatch. https://agrawatch.wordpress.com/2011/08/19/footloosefarmers/ [accessed February 26 2018]

AgroEcoEnergy. n.d. Inclusive growth. AgroEcoEnergy. http://www.ecoenergy.co.tz/sustainability/socialdevelopment/inclusive-growth/ [accessed March 1 2018]

Akram-Lodhi, A.H. 2008. (Re)imagining agrarian relations? The World Development Report 2008: agriculture for development. Development and Change 39(6): 1145-1161. DOI: http://10.1111/j.14677660.2008.00511.x

Amrine, F. 2010. The unconscious of nature: analyzing disenchantment in Faust I. Goethe Yearbook 17(1): 117-132.

Angelsen, A. and D. Kaimowitz. 2001a. Agricultural technologies and tropical deforestation. Wallingford: CABI Publishing.

Angelsen, A. and D. Kaimowitz. 2001b. When does technological change in agriculture promote deforestation? In Lee, D.R. and C.B. Barrett (eds.). Trade offs or synergies? Agricultural intensification, economic development and the environment. Wallingford: CAB International. Pp. 89114. 
Asafu-Adjaye, J., L. Blomquist, S. Brand, B. Brook, R. Defries, E. Ellis, C. Foreman, D. Keith, M. Lewis, M. Lynas, T. Nordhaus, R. Pielke Jr, R. Pritzker, R. Joyashree, M. Sagoff, M. Shellenberger, R. Stone, and P. Teague. 2015. An ecomodernist manifesto. Oakland: The Breakthrough Institute.

Bailey, I. and F. Caprotti. 2014. The green economy: functional domains and theoretical directions of enquiry. Environment and Planning A 46: 1797-1813.

Bailey, I. and G.A. Wilson. 2009. Theorising transitional pathways in response to climate change: technocentrism, ecocentrism, and the carbon economy. Environment and Planning A 41: 23242341.

Benjaminsen, T.A. and H. Svarstad. 2017. Politisk økologi - miljø, mennesker og makt. Oslo: Universitetsforlaget.

Bergius, M. 2014. Expanding the corporate food regime - the Southern Agricultural Growth Corridor of Tanzania - current and potential implication for rural households. Master thesis. Ås: Noragric, Norwegian University of Life Sciences (NMBU).

Bergius, M. 2016. Expanding the corporate food regime in Africa through agricultural growth corridors: the case of Tanzania. Global governance/politics, climate justice and agrarian/social justice: linkages and challenges - an international colloquium. 4-5 February 2016. The Hague.

Bergius, M., T.A. Benjaminsen and M. Widgren. 2018. Green economy, Scandinavian investments and agricultural modernization in Tanzania. The Journal of Peasant Studies 45(4): 825-852. DOI: http://10.1080/03066150.2016.1260554

Bernstein, H. 1971. Modernization theory and the sociological study of development. The Journal of Development Studies 7(2): 141-160. DOI: http://10.1080/00220387108421356

Bernstein, H. 2010. Class dynamics of agrarian change. Halifax: Kumarian Press.

Borras Jr, S.M. and J.C. Franco. 2018. The challenge of locating land-based climate change mitigation and adaptation politics within a social justice perspective: towards an idea of agrarian climate justice. Third World Quarterly. 39(7): 1308-1325. DOI: 10.1080/01436597.2018.1460592

Borras Jr, S.M., R. Hall, I. Scoones, B. White and W. Wolford. 2011. Towards a better understanding of global land grabbing: an editorial introduction. The Journal of Peasant Studies 38(2): 209-216. DOI: http://10.1080/03066150.2011.559005

Boserup, E. 1965. The conditions of agricultural growth: the economics of agrarian change under population pressure. London: Earthscan.

Brockington, D. 2012. A radically conservative vision? The challenge of UNEP's Towards a green economy. Development and change 43(1): 409-422. DOI: https://10.1111/j.1467-7660.2011.01750.x

Brown, E., J. Cloke, D. Gent and D. Hill. 2014. Green growth or ecological commodification: debating the green economy in the global south. Geografiska annaler: Series B 93(3): 245-259.

Buseth, J.T. 2017. The green economy in Tanzania: from global discourses to institutionalization. Geoforum 86: 42-52. DOI: https://doi.org/10.1016/j.geoforum.2017.08.015

Bushell, M. 2014. Improving smallholder agriculture. The 32nd Ralp Melville Memorial Lecture, delivered 10 December 2014 at the Royal Overseas League. London: TAA Forum.

Chandra A, K.E. McNamara and P. Dargusch. 2017. The relevance of political ecology perspectives for smallholder Climate-Smart Agriculture: a review. Journal of Poltiical Ecology 24: 821-842.

Clapp, J., P. Newell and Z.W. Brent. 2018. The global political economy of climate change, agriculture and food systems. The Journal of Peasant Studies 45(1): 80-88. DOI: http://doi.org/10.1080/03066150.2017.1381602

Collier, P. 2008. The politics of hunger: how illusion and greed fan the food crisis. Foreign Affairs 87(6): 6779.

Collins, D.E. and C. Kirtana. 2012. A wolf in sheep's clothing? An analysis of the 'sustainable intensification' of agriculture. Amsterdam: Friends of the Earth International. 
Consultative Group of International Agricultural Research (CGIAR). 1996. CGIAR annual report 1995-1996. Washington: CGIAR.

Conway, G. 1997. The doubly green revolution: food for all in the twenty first century. London: Penguin.

Corson, C., K.I. MacDonald and B. Neimark. 2013. Grabbing "green": markets, environmental governance and the materialization of natural capital. Human Geography 6(1): 1-15.

Currey, K. 2014. Some evolving trends at the World Bank: lending, funding, staffing. New York: Ford Foundation.

Daño, E.C. 2007. Unmasking the green revolution in Africa: motives, players and dynamics. Penang: Third World Network.

Davis, M. 2006. Planet of slums. New Perspectives Quarterly 23(2): 6-11. DOI: http://doi.org/10.1111/j.15405842.2006.00797.x book

Dawson, N., A. Martin and T. Sikor. 2016. Green revolution in Sub-Saharan Africa: implications of imposed innovation for the wellbeing of rural smallholders. World Development 78: 204-218. DOI: http://dx.doi.org/10.1016/j.worlddev.2015.10.008

Deen, T. 2009. UN seeks a green revolution. Global Policy Forum (GPF). https://www.globalpolicy.org/component/content/article/217/46162.html [accessed May 3 2018]

De Schutter, O. 2015. The New Alliance for Food Security and Nutrition in Africa. Brussels: European Parliament Committee on Development.

Delacroix, J. and C. Ragin. 1978. Modernizing institutions, mobilization, and third world development: a cross-national study. American Journal of Sociology 84(1): 123-150. DOI: http://doi.org/10.1086/226743.

Descartes, R. 1985. The philosophical writings of Descartes. Translated by J. Cottingham, R. Stoothoff and D. Murdoch. Vol. 1. Cambridge: Cambridge University Press.

Easterly, W. 1999. The ghost of financing gap: testing the growth model used in the international financial institutions. Journal of Development Economics 60(2): 423-438. DOI: https://doi.org/10.1016/S0304$\underline{3878(99) 00047-4}$

Eddens, A. 2017. White science and indigenous maize: the racial logics of the green revolution. The Journal of Peasant Studies. DOI: http://doi.org/10.1080/03066150.2017.1395857

Eggen, Ø. and K. Roland. 2013. Western aid at a crossroads - the end of paternalism. London: Palgrave Pivot.

Engström, L. and F. Hajdu. 2018. Conjuring 'win-world' - resilient development narratives in a large-scale agro-investment in Tanzania. Journal of Development Studies. DOI: http://doi.org/10.1080/00220388.2018.1438599.

ETC Group. 2015. Outsmarting nature? Synthetic biology and climate smart agriculture. Heinrich-BöllStiftung and ETC Group.

Evenson, R.E. and D. Gollin. 2003. Assessing the impact of the green revolution, 1960 to 2000. Science 300(5620):758-762. DOI: http://doi.org10.1126/science.1078710

Food and Agriculture Organization of the United Nations (FAO). 2010. The Hague conference on agriculture, food security and climate change. 'Climate-smart' agriculture policies, practices and financing for food security, adaptation and mitigation. Rome: FAO.

Frank, A.G. 1979. Dependent accumulation and underdevelopment. London: Macmillian.

Freebairn, D.K. 1995. Did the green revolution concentrate incomes? A quantitative study of research reports. World Development 23(2): 265-279. DOI: https://doi.org/10.1016/0305-750X(94)00116-G

Friedman, H. and P. McMichael. 1989. Agriculture and the state system: the rise and decline of national agricultures, 1870 to the present. Sociologia Ruralis 29(2): 93-117. https://doi.org/10.1111/j.14679523.1989.tb00360.x

Friedmann, H. 2005. From colonialism to green capitalism: social movements and emergence of food regimes. London: Emerald. 
Galenson, W. and H. Leibenstein. 1955. Investment criteria, productivity, and economic development. The Quarterly Journal of Economics 69(3): 343-370. DOI: http://doi.org.10.2307/1885846.

Gates, B. 2009. World food price symposium - prepared remarks by Bill Gates, co-chair and trustee. Bill and Melinda Gates Foundation https://www.gatesfoundation.org/Media-Center/Speeches/2009/10/BillGates-2009-World-Food-Prize-Symposium [accessed March 3 2018]

Gaud, W.S. 1968. The green revolution: accomplishments and apprehensions. Address to the Society of International Development. Washington, DC: AgBioWorld. http://www.agbioworld.org/biotechinfo/topics/borlaug/borlaug-green.html [accessed January 4 2018]

Gleeson, B. and N. Low. 1998. Justice, society and nature: an exploration of political ecology. London: Routledge.

Goldthorpe, J.E. 1975. The sociology of the third world: disparity and involvement. Cambridge: Cambridge University Press.

Greco, E. 2016. Village land politics and the legacy of Ujamaa. Review of African Political Economy 43(sup1): 22-40. DOI: http://doi.org/10.1080/03056244.2016.1219179

Green, M. 2015. After the MDGs: from social development to technoenterprise in Tanzania. Globalizations 12(4): 629-644. DOI: http://doi.org/10.1080/14747731.2015.1035551

Hall, R., I. Scoones and D. Tsikata. 2017. Plantations, outgrowers and commercial farming in Africa: agricultural commercialisation and implications for agrarian change. The Journal of Peasant Studies 44(3): 515-537. DOI: http://doi.org/10.1080/03066150.2016.1263187

Harvey, D. 1981. The spatial fix - Hegel, Von Thünen and Marx. Antipode 13(3): 1-12.

Harvey, D. 2001. Globalization and the "spatial fix" Geographical Review 3(2): 23-30.

Harvey, D. 2003. The new imperialism. Oxford: Oxford University Press.

Harvey, D. 2014. Seventeen contradictions and the end of capitalism. London: Profile Books Ltd.

Holt-Giménez, E. 2006. Campesino a campesino: voices from Latin America's farmer to farmer movement for sustainable agriculture. Oakland: Food First Books.

Holt-Giménez, E. and M.A. Altieri. 2012. Agroecology, food sovereignty, and the new green revolution. Agroecology and Sustainable Food Systems 37(1): 90-102. DOI: http://doi.org/10.1080/10440046.2012.716388

Holt-Giménez, E. and A. Shattuck. 2011. Food crises, food regimes and food movements: rumblings of reform or tides of transformation? The Journal of Peasant Studies 38(1): 109-144. DOI: http://doi.org/10.1080/03066150.2010.538578

Horlings, L.G. and T.K. Marsden. 2011. Towards the real green revolution? Exploring the conceptual dimensions of a new ecological modernisation of agriculture that could 'feed the world'. Global Environmental Change 21(2): 441-452. DOI: https://doi.org/10.1016/j.gloenvcha.2011.01.004

Hoselitz, B.F. 1953. The role of cities in the economic growth of underdeveloped countries. Journal of Political Economy 61(3): 195-208.

Hoselitz, B.F. 1955. Generative and parasitic cities. Economic Development and Cultural Change 3(3): 278294.

Hydén, G. 1980. Beyond Ujamaa in Tanzania: underdevelopment and an uncaptured peasantry. Berkeley: University of California Press.

International Fertilizer Association (IFA). 2012. 2012 Annual report. Paris: IFA.

Kremen, C. 2015. Reframing the land-sparing/ land-sharing debate for biodiversity conservation. Annals of the New York Academy of Sciences 1355(1): 52-76. DOI: https://doi.org/doi:10.1111/nyas.12845

Kröger, M. 2013. Globalization as the 'pulping' of landscapes: forestry capitalism's North-South territorial accumulation. Globalizations 10(6): 837-853. DOI: https://doi.org/10.1080/14747731.2013.814433

Kröger, M. 2015. Spatial causalities in resource rushes: notes from the Finnish mining boom. Journal of Agrarian Change. DOI: http://doi.org/10.1111/joac.12113 
Kwakkenbos, J. 2012. Private profit for public good? Can investing in private companies deliver for the poor? Brussels: European Network on Debt and Development (Eurodad).

Lappé, F.M. 2012. Beyond the scarcity scare: reframing the discourse of hunger with an eco-mind. The Journal of Peasant Studies 40(1): 219-238. DOI: http://doi.org/10.1080/03066150.2012.708859

Lappé, F.M. and J. Collins. 2015. World hunger - ten myths. New York: Grove Press.

Lewis, W.A. 1954. Economic development with unlimited supplies of labour. The Manchester School 22(2): 139-191. DOI: http://doi.org/10.1111/j.1467-9957.1954.tb00021.x

Li, T.M. 2007. The will to improve: governmentality, development, and the practice of politics. Durham and London: Duke University Press.

Li, T.M. 2010. To make live or let die? Rural dispossession and the protection of surplus populations. Antipode 41: 66-93. DOI: http://doi.org/10.1111/j.1467-8330.2009.00717.x

Li, T.M. 2011. Centering labor in the land grab debate. The Journal of Peasant Studies 38(2): 281-298. DOI: http://doi.org/10.1080/03066150.2011.559009

Logan, S. and G.R. Wekerle. 2008. Neoliberalizing environmental governance? Land trusts, private conservation and nature on the Oak Ridges Moraine. Geoforum 39(6): 2097-2108. DOI: https://doi.org/10.1016/j.geoforum.2008.08.009

Lopes, C. 2017. Africa's impala-like leap into a green industrial economy. The Guardian. https://www.theguardian.com/the-gef-partner-zone/2017/oct/23/africas-impala-like-leap-into-a-greenindustrial-economy [accessed April 17 2018]

Malthus, T. 1998 [1798]. Essay on the principle of population. London: Electronic Scholarly Publishing Project [accessed March 7 2014]

Marsden, T. 2010. Food 2030: Towards a redefinition of food? A commentary on the new United Kingdom government food strategy. The Political Quarterly 81(3): 443-446. DOI: http://doi.org/10.1111/j.1467923X.2010.02096.X

Marx, K. 1887. Das Kapital. Moscow: Progress Publishers.

McKeon, N. 2014. The New Alliance for Food Security and Nutrition: a coup for corporate capital? Amsterdam: Transnational Institute.

McKeon, N. 2015. Food security governance: empowering communities, regulating corporations. London: Routledge.

McMichael, P. 2009. Banking on agriculture: a review of the World Development Report 2008. Journal of Agrarian Change 9(2): 235-246. DOI: http://doi.org/10.1111/j.1471-0366.2009.00203.x

McMichael, P. 2012. Development and social change: a global perspective. 5th ed. London: SAGE.

Mol, A. P. J. and G. Spaargaren. 2000. Ecological modernisation theory in debate: a review. Environmental Politics 9(1): 17-49. DOI: http://doi.org/10.1080/09644010008414511

Moseley, W. 2017. The new green revolution for Africa: a political ecology critique. The Brown Journal of World Affairs 23(2): 177-190.

Moseley, W., M.A. Schnurr and R.B. Kerr (eds.). 2017. Africa's green revolution: critical perspectives on new agricultural technologies and systems. London: Routledge.

Mouzelis, N. 1980. Modernization, under development, uneven development: prospects for a theory of third world formations. The Journal of Peasant Studies 7(3): 353-374. DOI: http://doi.org/10.1080/03066158008438110

New Alliance. 2012. G8 cooperation framework to support The New Alliance for Food Security and Nutrition in Tanzania. G8.

Newell, P. and O. Taylor. 2018. Contested landscapes: the global political economy of climate-smart agriculture. The Journal of Peasant Studies 45(1): 108-129. DOI: http://doi.org/10.1080/03066150.2017.1324426 
Nilsen, A.G. 2016. Power, resistance and development in the global South: notes towards a critical research agenda. International Journal of Politics, Culture, and Society 29(3): 269-287. DOI: http://doi.org/10.1007/s10767-016-9224-8

Organization for Economic Co-operation and Development (OECD). 2009. Green growth. Overcoming the crisis and beyond. OECD Publishing, Paris.

OECD. 2011. Towards green growth. Paris: OECD.

OECD. 2012. Green growth and developing countries: a summary for policymakers. Paris: OECD.

Parsons, T. 1973. Comparative studies and evolutionary change. In I. Vallier (ed.). Comparative methods in sociology: essays on trends and applications. Berkeley: University of California Press. Pp. 97-141.

Parsons, T. 2005 [1951]. The social system. London: Routledge.

Patel, R. 2012. The long green revolution. The Journal of Peasant Studies 40(1): 1-63. DOI: http://doi.org/10.1080/03066150.2012.719224

Patel, R., R.B. Kerr, L. Shumba and L. Dakishoni. 2015. Cook, eat, man, woman: understanding the New Alliance for Food Security and Nutrition, nutritionism and its alternatives from Malawi. Journal of Peasant Studies. 42(1): 21-44.

Patel, R. and J. Moore. 2017. A history of the world in seven cheap things: a guide to capitalism, nature, and the future of the planet. California: University of California Press.

Pearce, D., A. Markandya and E. Barbier. 1989. Blueprint for a green economy. London: Earthscan.

Peet, R., P. Robbins and M.J. Watts. 2011. Global nature. In Peet, R., P. Robbins and M.J. Watts (eds.). Global political ecology. London: Routledge. Pp. 1-48.

Peet, R. and E. Hartwick. 2015. Theories of development: contentions, arguments, alternatives. New York: Guilford Publications.

Perfecto, I. and J. Vandermeer. 2010. The agroecological matrix as alternative to the land-sparing/agriculture intensification model. Proceedings of the National Academy of Sciences 107(13): 5786-5791.

Perfecto, I., J. Vandermeer and A. L. Wright. 2009. Nature's matrix: linking agriculture, conservation and food sovereignty. London: Earthscan.

Pimentel, D. and M. Pimentel. 1990. Comment: adverse environmental consequences of the green revolution. Population and Development Review 16: 329-332. DOI: http://doi.org/10.2307/2808081

Polanyi, K. 1944. The great transformation: the political and economic origins of our time. Vol. 2. Boston: Beacon Press.

Ponisio, L.C., L.K. M'Gonigle, K.C. Mace, J. Palomino, P. de Valpine and C. Kremen. 2015. Diversification practices reduce organic to conventional yield gap. Proceedings of the Royal Society B: Biological Sciences 282.

Prudham, S. 2013. Men and things: Karl Polanyi, primitive accumulation, and their relevance to a radical green political economy. Environment and Planning A. 45: 1569-1587. DOI: http://doi.org/10.1068/a45303

Rist, G. 2008. The history of development: from western origins to global faith. London: Zed.

Robbins, P. 2012. Political ecology: a critical introduction. $2^{\text {nd }}$ ed. Oxford: Wiley-Blackwell.

Rockefeller Foundation. 2006. Africa's turn - a new green revolution for the 21st century. New York: Rockefeller Foundation.

Rostow, W. 1960. Stages of growth: a non-communist manifesto. Cambridge: Cambridge University Press.

Sarraut, A. 1923. La mise en valeur des colonies françaises. Paris: Payot.

Southern Agricultural Growth Corridor of Tanzania (SAGCOT). 2013. A framework for agriculture green growth. Greenprint for SAGCOT. Dar es Salaam: SAGCOT.

Scoones, I., R. Smalley, R. Hall and D. Tsikata. 2014. Narratives of scarcity: understanding the 'global resource grab'. Future-Agricultures 76. Cape Town: PLAAS.

Shivji, I. G. 2008. Accumulation in an African periphery: a theoretical framework: African Books Collective. 
Spaargaren, G. and A.P.J. Mol. 1992. Sociology, environment, and modernity: ecological modernization as a theory of social change. Society and Natural Resources 5(4): 323-344. DOI: http://doi.org/10.1080/08941929209380797

Spencer, H. 1898. The principles of sociology. Vol. 1. New York: D. Appleton and Company.

Spitz, P. 2011[1987]. The green revolution re-examined in India. In B. Glaeser (ed.) The green revolution revisited. London: Routledge. Pp. 42-57.

Stern, D.I. 2004. The rise and fall of the environmental Kuznets curve. World Development 32(8): 1419-1439. DOI: https://doi.org/10.1016/j.worlddev.2004.03.004

Stroshane, T. 1997. The second contradiction of capitalism and Karl Polanyi's The Great Transformation. Capitalism Nature Socialism 8(3): 93-116. DOI: http://doi.org/10.1080/10455759709358751

Struik, P.C., T.W. Kuyper, L. Brussaard and C. Leeuwis. 2014. Deconstructing and unpacking scientific controversies in intensification and sustainability: why the tensions in concepts and values? Current Opinion in Environmental Sustainability 8: 80-88. DOI: https://doi.org/10.1016/j.cosust.2014.10.002

Taylor, M. 2018. Climate-smart agriculture: what is it good for? The Journal of Peasant Studies 45(1): 89107. DOI: http://doi.org/10.1080/03066150.2017.1312355

The Ecologist. 2015. No to 'Climate Smart Agriculture', yes to agroecology. The Ecologist. https://theecologist.org/2015/oct/21/no-climate-smart-agriculture-yes-agroecology [accessed April 27 2018]

The Guardian. 2017. Farmers encouraged to venture into modern rice farming. IPP Media. https://www.ippmedia.com/en/business/farmers-encouraged-venture-modern-rice-farming [accessed April 27 2018]

The Royal Society. 2009. Reaping the benefits: science and the sustainable intensification of global agriculture. London: The Royal Society.

Tienhaara, K. 2014. Varieties of green capitalism: economy and environment in the wake of the global financial crisis. Environmental Politics 23(2): 187-204. DOI: http://dx.doi.org/10.1080/09644016.2013.821828

Tiffen, M., M.J. Mortimore and F. Gichuki. 1994. More people, less erosion: environmental recovery in Kenya. Chichester: Wiley.

Tilzey, M. 2018. Political ecology, food regimes, and food sovereignty - crisis, resistance and resilience. London: Palgrave Macmillian.

Tittonell, P. 2014. Ecological intensification of agriculture - sustainable by nature. Current Opinion in Environmental Sustainability 8: 53-61. DOI: https://doi.org/10.1016/j.cosust.2014.08.006

Tomlinson, I. 2013. Doubling food production to feed the 9 billion: a critical perspective on a key discourse of food security in the UK. Journal of Rural Studies 29: 81-90. DOI: https://doi.org/10.1016/j.jrurstud.2011.09.001

Truman, H.S. 1949. Truman's inaugural address, January 20, 1949. The Harry S. Truman Library. https://www.trumanlibrary.org/whistlestop/50yr_archive/inagural20jan1949.htm [accessed October 23 2015]

United Nations Department of Economic and Social Affairs (UNDESA). 2011. World economic and social survey 2011: The great, green technological transformation. New York: United Nations. http://www.un.org/en/development/desa/policy/wess/wess current/2011wess.pdf $[$ accessed May 3 2018]

UNEP. 2011a. Towards a green economy: pathways to sustainable development and poverty eradication. Nairobi: UNEP.

UNEP. 2011b. Towards a green economy: pathways to sustainable development and poverty eradication - a synthesis for policymakers. Nairobi: UNEP.

Walwa, J. W. 2017. Land use plans in Tanzania: repertoires of domination or solutions to rising farmerherder conflicts? Journal of Eastern African Studies 11(3): 408-424. 
Wallerstein, I. 2004. World-systems analysis: an introduction. Durham: Duke University Press.

Wanner, T. 2015. The new 'passive revolution' of the green economy and growth discourse: maintaining the 'sustainable development' of neoliberal aapitalism. New Political Economy 20(1): 21-41.

World Commission on Environment and Development (WCED). 1987. Our common future. Oxford: Oxford University Press.

World Economic Forum (WEF). 2010. Realizing a new vision for agriculture: a roadmap for stakeholders. Geneva: WEF.

WEF. 2016. Grow Africa: partnering to achieve African agriculture transformation. Geneva: World Economic Forum.

WEF. 2018. Innovation with a purpose: the role of technology innovation in accelerating food systems transformation. Geneva: World Economic Forum.

Westengen, O.T., P. Nyanga, D. Chibamba, M. Guillen-Royo and D. Banik. 2017. A climate for commerce: the political agronomy of conservation agriculture in Zambia. Agriculture and Human Values. DOI: http://doi.org/10.1007/s10460-017-9820-x

White, J.M. 2013. The new alliance for food security and nutrition: pushing the frontiers of enlightened capitalism. Washington, DC: German Marshall Fund of the United States.

World Bank. 2007. World development report 2008. Washington: World Bank.

World Bank. 2012. Inclusive green growth: the pathway to sustainable development. Washington, D.C: World Bank.

World Bank. 2013. Growing Africa: unlocking the potential of agribusiness. Washington: World Bank.

World Bank. 2017. Enabling the business of agriculture 2017. Washington: World Bank.

Yara. 2015. Climate smart agriculture. Oslo: Yara.

Yara. n.d.-a. Green growth. Oslo: Yara. http://yara.com/sustainability/how we engage/green growth/ [accessed February 15 2018]

Yara. n.d.-b. Hosting the African green revolution conferences. Oslo: Yara.

Yara. n.d.-c. Smarter farming: sustainable intensification. Oslo: Yara. http://yara.com/sustainability/climate smart agriculture/smarter farming/ [accessed February 15 2018]

York, R. and E.A. Rosa. 2003. Key challenges to ecological modernization theory: institutional efficacy, case study evidence, units of analysis, and the pace of eco-efficiency. Organization and Environment 16(3): 273-288.

Zhou, Y. 2010. Smallholder agriculture, sustainability and the Syngenta Foundation. Syngenta Foundation. 